【総説】

\title{
補完代替医療を科学的に評価 する無作為化比較試験 \\ Randomized Controlled Trials for Creating Scientific Evidence of the Efficacy and Safety of Complementary and Alternative Medicine
}

\section{丹 後 俊 郎 \\ Toshiro TANGO}

\section{国立保健医療科学院技術評価部}

\begin{abstract}
【要 旨】
無作為化比較試験（RCT, randomized controlled trial）が新しい治療法の効果を評価するために ヒトに施される実験であり，かつまた，それが 最も質の高い科学的なエビデンスを提供してく れる唯一の研究デザインであることは世界的に 広く認められた事実である。一方，日本では， RCT に対する関心とその重要性への認識は低 く，薬効評価の分野でも質の高い RCT はきわ めて少なかった。最近の科学的根拠に基づく医 療（EBM）の流行により RCT に対する関心は 高まっているものの，RCT を正しく理解して実 践できる臨床医，製薬メ一カの臨床開発担当者 は少ない，このことは補完代替医療の評価に拈 いても全く同様にあてはまる. RCT を正しく理 解し，デザインし，その結果を正しく評価でき る研究者, 実務家の養成は急務である。本小論 では，RCT とは何か，RCTをデザインする上 で必要不可欠な統計学的考方方を解説する。
\end{abstract}

【キーワード】

効果の大きさ, 無作為割付, バイアス, 交絡因子

\section{1.はじめに}

補完代替医療学会の最大の目的は，今日利用されてい る様々な補完代替医療のヒトに対する有効性と安全性を 科学的に証明することであり，ひいては，科学的な根拠 を持つ補完代替医療の数を増加させ，国民が安心して補 完代替医療を利用できるようにすることであろう。日本 に拈いて，これまでの（現在でもそらであるが）健康補 助食品， $\mathrm{x} x \mathrm{x}$ 療法で代表される補完代替医療の効能の 宣伝広告では，臣とんどが「動物実験で優れた x x x の 力を有することが証明された」「ｘｘｘ を摂取すること で免疫力を高め, 健康の維持, 増進 ...」「 $\mathrm{x} x \mathrm{x}$ を摂取 することで x x x 障害を改善するといらことが学会発 表されました」といら内容，あるいは，使用者からの「効 いた」といら抔りをたくさん掲載して，効果ありの根 拠として提示しているケースが多い. 効く可能性と期待 感を匂わせているものの，ヒトで科学的に証明されたと いう「根拠」の提示は皆無に近い。これでは，実際にヒ トでの有効性を確かめていないにも係わらず，「効く」と 称して高価な商品を販売している「ペテン師」と何一つ 違わないといわれても仕方ないのではないだろらか？

ヒトに対する有効性を科学的に証明する最も優れた研 究デザインは無作為化比較試験（Randomized controlled trials）であり，医薬品の許認可ではその適用は必須となっ ていることは周知の事実である。一方，安全性・リスク を検討する研究デザインでは，ヒトにリスクを無作為割 付することが不可能なため, 観察研究としての疫学研究 (Epidemiological study) に依存せざるを得ない.しかし， リスクのエビデンスレベルを向上させるためには，可能 なかぎり健康に良いと思われる方向に介入できるオプ ションを有する介入研究 (Intervention study) を実施すべ きである.このデザインは狭義の意味での RCT とも言わ れる，本小論では，補完代替医療の有効性と安全性を科 学的に証明するための RCT を普及させることを目標と して， RCT がなぜ必要なのか，その実践方法は，そして， 必要な統計学的な考方を解説したい.

\section{2. なぜ RCT？}

RCT は治療法（treatment）を比較するために持ち込ま れた科学的な方法である。その方法に拈ける治療法の良 し悪しは，理論（もらろん何らかの狭義の薬理作用に関 する理論があるかもしれないが...) に基づくというより 
は実際にヒトに適用して得られた治療結果を観察するこ とに基づいて評価するものである，決して，その道の権 威の判断を仰ぐ，あるいは，だれかの意見を参考にする ものではない，つまり， RCT は，実験・観察によって得 られた被検者（以下，患者）の反応データに基いて治療 効果を評価するものである，同一の治療を施された患者 がすべて同じように反応するわけでもない，改善傾向を 示す者もいれば, 残念ながら悪化してしまら患者もいる. 同一の治療群でもこのようなバラッキ（within variation） があることを認めた上で，「新治療群と対照群との差 （between variation）」を評価するのが RCT であり，これ はまさに統計学的推測（statistical inference）の問題であ る。また， RCT の結果が RCT に参加しなかった他の患 者集団にも一般化できなければ RCT を実施する意味が ない. この標本から母集団への推測は古典的な統計的推 測である．当然のことながら，データの質が悪ければい かなる統計的計算も無䭾になるのでデータの質を高める ことが極めて重要となることは言うまでない，このよう に RCT のデザインから評価にいたるまで, 統計学的要素 が充満している事に気が付いただろうか？したがって, RCT では

1. 実施可能なデザインを計画し実施（データをとる） する治療法の専門家

2. 評価可能なデザインを計画し統計解析を行ら統計 家 (statistician)

の二つの存在が必要不可欠となる.

\section{3. 同時対照の必要性}

なぜ，対照群を置くのだろらか？新治療群の一本 （single arm）で十分ではないか? どのような治療も有効 でなく，結核でヒトがばたばたと亡くなっていくことを 経験してきた医師のだれもが「この新しい治療法は明ら かに効果が絶大だ」と言えた抗生物質の上らな治療法は 最近では極めて希なことだろう。むしろ，

・何もしなくても自然治癒, 自然軽快が起こりえる疾患 が多い,

・薬物治療では，それに対する反応性，代謝などに個人 差が大きく，それに比べると治療効果は小さい，

- 治療以外の要因による見かけの軽快・治癒が生じる,

このような状況では，すべての患者にある新しい治療 法だけを適用した場合，改善（あるいは悪化）したとし ても，その原因が新しい治療の作用なのか他の要因の作 用なのかの区別がわからないことになってしまう。した がって，その区別を行ら方法としては新しい治療を受 けない別の群を設けることにより，その群との比較の上
で新しい治療法の有效性が議論できることになる。この 別の群を対照群（control group）あるいは同時対照群 (concurrent control group) と言う。最初の RCT は英国の BMRC（British Medical Research Coucil）が行った肺結核 患者治療のストレプトマイシンの効果であると言われて いる. 従来の安静療法を対照として行われ，「安静療法で 観察された効果」を差し引くことの重要性を指摘したの である。もちろん，対照群の選び方は無条件ではない．

1. 新しい治療法以外の治療法といっても, 当然ながら, 新しい治療法より劣っていることが分かっている治 療法は選べない，その時点で最も効果のある治療法 を選ぶべきであり，治療法の有効性・安全性の優劣 がわからない（科学的なエビデンスがないという意 味で個々の臨床医の主観的判断ではない）から RCT を行らのである。もしそのような標準治療薬がなけ れば対照群にはプラセボ（placebo）を投与すること になる。

2. 治療群と対照群という構成は最も単純な RCT の構 成であるが，同一治療で用量を変えて用量反応性を 検討し，至適固定用量の選択を行う試験では 3 群以 上が普通となる。

3. 比較される群は治療開始直前の時点ではあらゆる点 で似ている必要がある。異なるのは，これから適用 される治療法だけといら比較可能性を担保すること が極めて重要である。

結局，ある治療の「治療効果」とは絶対的な測度では なくあくまで比較している別の治療法に対する相対的な 測度であることに注意しなければならない，特にプラセ ボ対照に抢ける相対的な大きさを治療の「効果の大きさ (Effect size)」という.

\section{4. 無作為化の重要性}

一方，何故「無作為に割り付けるのか」という命題は 簡単には理解できないかもしれない，そこで，治療効果 を考えるために, 治療法 A と治療法 B の比較を考えるた めにまず，表 1 に示す実験を考えてみよう。治療の効果 を評価する尺度としてある検査值 Xを考兄，検査值が減 少すれば「効果がありそう」と考光，その大きさを「減 少量」で評価するものと考光る。ある一人の患者に対し

表 1 一人の患者に対する理想的な試験デザイン

\begin{tabular}{cccc}
\hline & 時点 $t_{0}$ & & 時点 $t_{1}$ \\
\hline A 治療法 : & $x_{0}$ & $\Rightarrow$ & $x_{A}$ \\
B 治療法 : & $x_{0}$ & $\Rightarrow$ & $x_{B}$ \\
\hline
\end{tabular}


て時点 $t_{0}$ で治療法 $\mathrm{A}$ を開始し時点 $t_{1}$ でその効果を評価 するものとする. 時点 $t_{0}$ での検查值が $X_{0}$ であり, 時点 $t_{1}$ での検查值が $X_{A}$ であれば治療法 $\mathrm{A}$ を投与した結果と して検査值は $X_{0}-X_{A}$ だけ減少したことになる。一方，治 療法 B についても，もし，全く同じ患者に全く同じ時点 $t_{0}$ で治療法 B を開始し, 全く同じ時点 $t_{1}$ で評価できるも のと仮定しょう.すなわち, 時点 $t_{0}$ の検查值は先ほどと 同じ $X_{0}$ であるが, 治療法 B の結果として時点 $t_{1}$ での検 查值が $X_{B}$ であったとしょう。治療法 B の結果として検 查值は $X_{0}-X_{B}$ だけ減少しているから, ある一人の患者に 対する治療法 A の B V対する効果の大きさは

$$
\text { Effect size }=\left(X_{0}-X_{A}\right)-\left(X_{0}-X_{B}\right)=X_{B}-X_{A}
$$

と計算できることになる．患者母集団から無作為に抽出 された $n$ 人の患者を対象に同じ試験を独立に繰り返すこ とにより効果の大きさの分布, 平均的な効果の大きさ, 患者の特性に応じた治療効果などが推測できることにな る.しかし，このような実験は明らかに不可能である。 異なった 2 種類の治療法を同時に開始することは可能で あっても, 評価時点にそれぞれの治療法に反応した検査 值の大きさ $X_{A}, A_{B}$ をそれぞれ独立に測定することは不 可能であるからである. 現実には $X_{A}=X_{B}$ となる.

そこで，同じ患者に対しては同時進行で比較できない のなら，違う時点を選べば比較することができるのでは ないだろらか? そこで表 2 に示寸実験を考光るてみよ う。つまり, 治療法 A の評価が終了してから治療法 B の 評価を試みるデザインである。この場合の治療法 A の B に対する効果の大きさは

$$
\text { Effect size }=\left(X_{0}-X_{A}\right)-\left(X_{2}-X_{B}\right)
$$

と計算できることになる。これなら，確かにうまくいき そらかもしれない。しかし，このデザインにも次の落と し穴が...

・治療法 A によりほぼ完治してしまうと治療法 B の出 番はなくなる。

・先に治療法 A を施しているため，その影響（心理的な ものも含め）が治療法 B を実施する場合にでてしまう (順番の効果).

・治療法 B を開始する時期が早過ぎると治療法 A の効

表 2 一人の患者に対する時点を変えた試験デザイン，当然な

\begin{tabular}{|c|c|c|c|c|c|c|}
\hline & 時点 $t_{0}$ & & 時点 $t_{1}$ & 時点 $t_{2}$ & & 時点 $t_{3}$ \\
\hline A 治療法： & $x_{0}$ & $\Rightarrow$ & $x_{A}$ & & & \\
\hline B 治療法 : & & & & $x_{2}$ & $\Rightarrow$ & $x_{B}$ \\
\hline
\end{tabular}
がら $t_{3}-t_{2}=t_{1}-t_{0}$. 果がまだ残存している持ち越し効果（carry-over）が問 題となる.

・治療開始時点が異なるということは，同じ患者であっ ても「状態が異なる」といらこと．つまり，個体内変 動によって治療開始の「初期条件」が異なり治療への 反応性が変化する（交絡という）可能性が大きい場合 には治療法 A と B とを対等に比較できない.

したがって，通常は表 3 に示すように，治療法 A，治療 法 B を独立にそれぞれ $n_{A}, n_{B}$ 人の患者に実施し，その結 果を比較するデザインが多い。これを並行群間比較試験 (parallel group design) と言う。ただし $n_{A}=n_{B}=n$ とする のが検出力が最も高いので望ましい.

さて，このデザインでは，治療法 A，Bには異なった 患者で構成されているので, 同じ疾患の患者と言えども， 一人一人，当然ながら治療開始時の初期状態（条件）が 病状，年齢，性など様々な要因で異なる。したがって， 治療への反応性も異なる。この混沌とした状況の中で, それぞれの治療法の成績を A 群と B 群で対等に比較す るためには，「操作的に」各群の初期状態の分布を同じく する工夫が重要なポイントとなる，当然，全く同じには なりえないが, 極めて似た分布にすることは可能である. それが「無作為に治療法を割り付ける」確率操作である. この無作為割り付け (random allocation) よって, 平均的 には類似した初期状態が確保される。言い換えれば比較 可能性（comparability）が達成される.こうすることに よって無意識のらちに計算されてきた平均值の比較で

$$
\text { Effect size }=\frac{\sum_{i=1}^{n_{A}}\left(X_{A 0 i}-X_{A i}\right)}{n_{A}}-\frac{\sum_{i=1}^{n_{B}}\left(X_{B 0 i}-X_{B i}\right)}{n_{B}}
$$

と計算できることになる。逆にいえば，無作為割り付け を行わない比較試験で計算された上式の結果は一体何を 表すのだろらか? すくなくとも，その再現性は極めて乏 しく，正しい治療効果を表現できていない。これは無作 為割り付けのもつ倫理的問題以上に, 数多くの患者に参 加していただいて扣きながら，再現性のない，解釈が難 しい結果を出すことの倫理上の問題が大きくクローズ アップされなければならない。

この無作為割り付けは，同一患者に対して治療法 A, $\mathrm{B}$ を時間を変えて行らデザインにも全く同様にあてはま

表 3 並行群間比較試験のデザイン

\begin{tabular}{ccccc}
\hline & 時点 $t_{0 i}$ & & 時点 $t_{1 i}$ & \\
\hline A 治療法 : & $x_{A 0 i}$ & $\Rightarrow$ & $x_{A i}$ & $\left(i=1, \ldots, n_{A}\right)$ \\
B 治療法 : & $x_{B 0 i}$ & $\Rightarrow$ & $x_{A i}$ & $\left(i=1, \ldots, n_{B}\right)$ \\
\hline
\end{tabular}


表 4 クロスオーバーデザイン

\begin{tabular}{|c|c|c|c|c|c|c|c|}
\hline & \multicolumn{3}{|c|}{1 回目の試験期間 } & \multicolumn{3}{|c|}{2 回目の試験期間 } & \\
\hline & \multicolumn{2}{|l|}{ 時点 $t_{0 i}$} & 時点 $t_{1 i}$ & 時点 $t_{2 i}$ & & 時点 $t_{3 i}$ & \\
\hline \multirow[t]{2}{*}{ 群 1} & & 療法 & & & 療注 & & \\
\hline & $x_{A 0 i}^{(1)}$ & $\Rightarrow$ & $x_{A i}^{(1)}$ & $x_{B 0 i}^{(1)}$ & $\Rightarrow$ & $x_{B i}^{(1)}$ & $\left(i=1, \ldots, n_{1}\right)$ \\
\hline \multirow[t]{2}{*}{ 群 2} & & 療法 & & & 療江 & & \\
\hline & $x_{B 0 i}^{(2)}$ & $\Rightarrow$ & $x_{B i}^{(2)}$ & $x_{A 0 i}^{(2)}$ & $\Rightarrow$ & $x_{A i}^{(2)}$ & $\left(i=1, \ldots, n_{2}\right)$ \\
\hline
\end{tabular}

る. 持ち越し効果の影響が無視できるほどの期間を置き, かつ，個体内変動の影響が無視できる場合には，治療法 B の次に治療法 A を実施するといら順番を逆にする患者 群を導入することにより，治療法の順番の影響を排除し よらとするクロスオーバーデザイン (crossover design) が 可能である (表 4). テニスのコートチェンジ, サッカー での... と同じ意味をもつ．このデザインでは，治療法 A の次に治療法 B を行ら群 1, その逆の群 2, それぞれ について 1 回目の平均値から 2 回目の平均値の差を, そ れぞれ， $\bar{d}_{1}$ (治療法 A の B に対する Effect size)， $\bar{d}_{2}$ （治 療法 BのA に対する Effect size）を計算する.

$$
\begin{aligned}
& \bar{d}_{1}=\frac{\sum_{i=1}^{n 1}\left(X_{A 0 i}^{(1)}-X_{A i}^{(1)}\right)}{n_{1}}-\frac{\sum_{i=1}^{n 1}\left(X_{B 0 i}^{(1)}-X_{B i}^{(1)}\right)}{n_{1}} \\
& \bar{d}_{2}=\frac{\sum_{i=1}^{n 2}\left(X_{B 0 i}^{(2)}-X_{B i}^{(2)}\right)}{n_{2}}-\frac{\sum_{i=1}^{n 2}\left(X_{A 0 i}^{(2)}-X_{A i}^{(2)}\right)}{n_{2}}
\end{aligned}
$$

持ち越し効果の影響と個体内変動（時期）の影響が無視 できる場合には治療法 A D B に対する Effect size は

$$
\text { クロスオーバーデザインでの Effect size }=\frac{\bar{d}_{1}-\bar{d}_{2}}{2}
$$

と期待される。しかし，持ち越し効果の可能性が否定で きない場合には解釈が難しい，最後に，無作為化の確率 操作の効用をまとめると次のようになる.

1. 比較可能性：それぞれの治療群で制御不可能なすべ ての要因の分布が同じよらな分布に均一化される, 特に現在の知識では分からない未知の交絡因子まで も均一化することができること，

2. 統計解析の簡単化: 均一化により, 治療前に観測さ れるデータのバラッキの大きさがほぼ等しくなるこ とが期待され (等分散性), 統計解析の結果の解釈を 容易にしてくれる.

\section{5. 倫理的問題}

RCT は本質的に実験である，と解説したものの医学の 世界でこれが当たり前になったのは極めて最近のことで
ある. 他の分野の科学者は何世紀にもわたって実験を 行ってきているわけで，RCT だけに何か特別な要素があ るか，といえば，それは「実験的単位がヒト」といら点 であろら。これゆ完，実験者には様々な倫理的責任が課 せられることになる。ここで倫理について詳しく解説す るつもりはないが，なかでも重要なポイントは次の点で ある。

1.「劣っている」と分かっている治療を患者に適用して はならない。

2. 患者には治療に関するあらゆる情報，可能な副作用 などに関する十分な説明を行い，同意した上で試験 に参加（informed consent）させる必要がある。

3. 一旦試験に参加した患者でも患者の意思でいつでも 試験から脱落することができ，その場合にはその時 点で最も最良と思われる治療を受けられることを保 証しなければならない。

これらの患者の利益は, ヒトに実施される実験, 介入 試験への倫理的指針をまとめたへルシンキ宣言

（Declaration of Helsinki）で守られている.

さて，RCT の重要な要素である「治療を無作為に割り 付ける行為」そのものが上記の 1 . 亿該当する可能性が あるだろらか？だれしも，乱数で自分の運命が左右され たのではたまったものではないと感じるであろら。その 患者に有効なはずの（担当医師が経験的にそう思ってい るだけにすぎない）治療を受ける機会が奪われるといっ て RCT は倫理上問題があり実施できないと主張する臨 床医が多い。一方で，ある治療法を $2-3$ 人の患者に実施 して成績が続けて良かったりするとその治療法が良いと 思い込んでしまう主観的判断が問題である。そこで，PC の乱数発生機能を利用して 500 個の 0,1 の乱数列を表示 してみよう。それぞれの生起確率は等確率（=1/2）であ る. 500 個の中で 0,1 の頻度はそれぞれ 250 個に近く, それぞれ約半数出現していることがわかるだろう。とこ ろが, 任意の 10 個の数列をとってみると 0 が 8 回程度連 続して現れている，または，逆に 1 が 8 回程度連続して いるところがあるだろら。つまり，2 回に 1 回の出現が 
期待される事象であっても，一方が何度も連続して出現 することがよくあることを示している。つまり臨床医の 経験がこの乱数列のどの局面にいたかで治療法に対する 「思い」が大きく変化してしまらのである.

また，治療法には，すべて，それを支持する人，批判 的な人，無関心な人が抒り，中立的な立場の人は少ない ものである。したがって，その治療法が有効であると主 張する客観的な証拠を提示しない限り，その治療法に熱 心な集団を除いては，誰も評価はしてくれない！

1. 対照も置かず，無作為割り付けもせずに実施された 研究（オープン試験）では当該治療法に都合よい方 向に偏った結論を導いたが,

2. 後にきちんと対照群を置いて比較試験を実施した結 果, 対照群に比較して有意に劣ってしまった といら事例は，公表バイアス（publication bias）を考慮す るとかなりの頻度にのぼるものと推測される。したがっ て,「治療法 A と治療法 B のどちらが有効かが誰も分か らない状況下で行わ秃る RCT の無作為割り付けには倫 理上の問題はない」と宣言できるのではないだろらか. むしろ, 比較可能性が乏しいデータに「正しい統計手法」 を適用して䛊った結果を導くことのほうがはるかに倫理 上の問題があるように思われる，将来，その結果に基づ いて発生するであらら不必要な研究に費やされる不幸な 研究者之研究協力者, 費用, 時間の地球規模の損失, 不 必要でかつ不適切な治療を受けることになる最も不幸な 患者群，を考えてみてほしい，なにが正しいか理解でき
るだろう。

$$
\text { 6. エンドポイント }
$$

科学的実験の最大の目的は真実を発見することであ ろう，真実を発見するには正確かつ精密に測定できな ければならない，RCTの最大の目的も治療法の効果 （Effect size）を正確かつ精密に測定（推定）することに ある，そのためには，治療効果を正確かつ精密に測定で きるエンドポイント (endpoints)，あるいはアウトカム変 数 (outcome variables, outcome measures) を検討すること は極めて重要である，思いつくままに筆者が経験した臨 床試験でのエンドポイントを表 5 に掲載した。そそれぞれ， 疾患の特徵を反映したエンドポイントが導入されている が，その妥当性の検討が十分になされた結果かといらと 必ずしもそうでないようである。一つの測定值自身が工 ンドポイントになる場合もあるし，多くの変数の合成得 点としての「スコア」がエンドポイントとなる場合もあ る。いずれにしても，エンドポイントとして採用する場 合には，その妥当性（正確度と精密度）に関する検討が 必要である. 更に, 多施設共同試験の場合は施設間差を 無く（小さく）する工夫も重要である. エンドポイント が臨床検查項目であれば，統一測定はその工夫の典型で ある。つい最近まで日本で頻繁に使用されてきた「主治 医判定」は治療効果の特徵を消し, かつ, 主治医の経験, 主観の差なぞよる担当医間差（施設間差）が大きい極め

表 5 臨床試験で使用されたエンドポイントの例

\begin{tabular}{|c|c|}
\hline 疾患 & エンドポイント \\
\hline がん患者 & $\begin{array}{l}\text { 死亡 (overall, disease-specific) } \\
\text { 無症候期間 (disease-free interval), QOL }\end{array}$ \\
\hline HIV 陽性, AIDS & $\mathrm{CD} 4, \mathrm{CD} 4 \% \mathrm{CD} 8, \mathrm{CD} 8 \%$, 死亡 \\
\hline 脳梗塞（急性期）患者 & $\begin{array}{l}\text { Modified Rankin Scale, Japan Stroke Scale } \\
\text { Glasgow Outcome Scale, NIH Stroke Scale }\end{array}$ \\
\hline 勃起不全患者 & 性交に十分な硬さの勃起に達した回数, 性交出来た回数 \\
\hline 慢性リンパ性白血病患者 & 日本癌治療学会の固形がん化学療法直接効果判定基準 \\
\hline 本態性高血圧症 & 收縮期血圧，拡張期血圧，トラフ/ピーク比（24 時間血圧） \\
\hline 通年性鼻アレルギー & 鼻症状 (くしゃみ発作, 鼻汁, 鼻閉) スコア (患者日誌) \\
\hline 慢性蔚麻疹, アトピー性皮膚炎 & 掻痒の症状スコア（患者日誌） \\
\hline B 型慢性活動性肝炎 & DNA-polymerase, HBe 抗原, 肝機能改善度（ALT） \\
\hline C 型慢性肝炎 & 肝機能改善度 (ALT), HAI スコア, 繊維化の分類基準 \\
\hline C 型慢性肝炎高ウイルス血症 & HCV-RNA の陰性化 \\
\hline 肝硬変に伴ら筋痤攣（こむら返り） & 筋痤攣の出現回数 \\
\hline 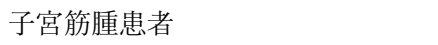 & 子宮筋腫核体積の縮小率, 症状の改善 \\
\hline 中枢性思春期早発症 & $\begin{array}{l}\text { ゴナドトロピン分泌抑制，性腺ホルモン分泌抑制 } \\
\text { 二次性徴の退行あるいは進行抑制 }\end{array}$ \\
\hline 喘息 & 発作の頻度, QOL, $\mathrm{FEV}_{1}, \mathrm{FVC}$ \\
\hline
\end{tabular}


て不適切なエンドポイントであった.

一般に，治療効果を測定するためのエンドポイントは いくらでも探すことができるかもしれない。しかし，観 察される “効き目”は変数によって異なる. 重要なこと は，エンドポイントの候補となる変数の中から，理論的 にもある程度サポートされ, かつ観察される“効き目”が 最大と期待される「变数あるいは変数群」を選択するこ とである，複数のエンドポイントが選択された場合，治 療効果ありと判定するためのルールとしては, 次の二つ が一般的である.

・すべてのエンドポイントが統計学的に有意となる必要 がある

・すくなくとも一つのエンドポイントが統計学的に有意 となればよい

前者の場合は「治療効果の内容」から必然的に複数の エンドポイントが同時に満足されなければならないこと が導かれる場合である. 後者の場合は，どのエンドポイ ントも同程度の効き目が期待され，どれが最適なエンド ポイントが迷ら場合に複数選択される。しかし，この場 合は検定の多重性の問題が生じ，エンドポイントの数が 増えれば検出力は必然的に落ちるので数の決定には慎重 を要する。

時には，治療効果の測定が簡単でない場合もある。例 えば，肝硬変患者の「腹水」を減少させる効果をもつと 考えられる治療法のエンドポイントとしては何が適切だ ろらか？腹水のある場所，形，体積が患者によって異な り，複数の部位の可能性がある. 治療効果を正確に評価 するといら観点から, 腹部全体に存在する腹水を同定し, その体積（重量）を計測する工夫を考えるべきであろう。 既存の検査が存在しないからといって，簡単に計測でき る「体重の変化」だけで代替できると考えるべきではな いだろら。

\section{7. バイアス}

一般に測定には誤差（error）がつきものである．真值 が $\theta$ である物質の測定值を $x$ とすると䛊差 $\varepsilon$ は

$$
\varepsilon=x-\theta
$$

である．測定操作のミスを除けば，誤差の中身は大きく 分けて

1. 精密度 (precision), 言いかえれば偶然誤差 (random error)

2. 正確度 (accuracy)，言いかえればバイアス（bias）あ るいは系統誤差（systematic error）

の二つに分解できる. 真值 $\theta$ をもつ試料を $n$ 回「繰り返
し測定」したときの第 $j$ 回目の測定值 $x_{j}$ を母平均 $\mu$ ，母 分散 $\sigma_{E}^{2}$ の正規分布にしたがう変量と考えてみよう。平 均值 $\bar{x}$ を利用すると，第 $j$ 回目の誤差は

$$
\varepsilon_{j}=\left(x_{j}-\bar{x}\right)+(\bar{x}-\theta), j=1,2 \ldots, n \text { (反復) }
$$

と分解される. ここで，第 1 項は偏差（deviation）と呼 ばれ，母平均 $\mu$ の推定值である平均值 $\bar{x}$ のまわりの $x_{j}$ の バラッキ，つまり測定法の「精密度」を意味する。 その 平均的な大きさは母標準偏差 $\sigma_{E}$ の推定值としての標準 偏差 SD（standard deviation）

$$
S D=\sqrt{\frac{\sum_{j=1}^{n}\left(x_{j}-\bar{x}\right)^{2}}{n-1}}
$$

で推定できる。，一方，第 2 項 $(\bar{x}-\theta)$ は真值からの偏り $(\mu-\theta)$ の推定值を表わす。いいかえれば測定法の「バ イアス」を表す。 $\mu=\theta$ であれば $\bar{x} は$ は $\theta$ 不変推定量 (unbiased estimator) である.

$\mathrm{RCT}$ も同様である。治療法 A と B とを比較する RCT のエンドポイントをそれぞれ確率変数 $X_{A}, X_{B}$ で表すこ とにする。今，治療法それぞれの効果が

$$
\begin{aligned}
& X_{A}=\mu+\theta_{A}+\varepsilon_{A} \\
& X_{B}=\mu+\theta_{B}+\varepsilon_{B}
\end{aligned}
$$

と表現されるとき，治療効果の差は

$$
\theta=\theta_{A}-\theta_{B}
$$

と定義される. RCT の目的は $\theta$ を推定することにある. もし並行群間比較試験が完璧に理想的な環境で実施され たとしたら, 平均值の差 $\bar{X}_{A}-\bar{X}_{B}$ は $\theta$ の不変推定量とな るだろら。すなわち

$$
E\left(\bar{X}_{A}\right)-E\left(\bar{X}_{B}\right)=\theta
$$

しかし，RCTの実施に拈いては，様々な要因で誤差と 治療効果以外の要因によるバイアスが混入し

となって

$$
\begin{aligned}
& X_{A}=\mu+\theta_{A}+\xi_{A}+\varepsilon_{A} \\
& X_{B}=\mu+\theta_{B}+\xi_{B}+\varepsilon_{B}
\end{aligned}
$$

$$
E\left(\bar{X}_{A}\right)-E\left(\bar{X}_{B}\right)=\theta+\xi_{A}-\xi_{B} \neq \theta
$$

となり，平均值の差は不偏推定量とはならない可能性が 大である. RCT のデザインの目的の一つはこのバイアス $\xi_{A}-\xi_{B}$ をできるだけ小さくすることにある. バイアスは 主に

1. 選択バイアス（selection bias）

2. 評価バイアス（assessment bias）

3. 割り付けバイアス（allocation bias） 
4. 公表バイアス (publication bias)

の 4 つに分類される.

\section{1 選択バイアス}

選択バイアスは大きくわけると，RCTへのエントリー 時点と RCT の期間が終了して結果を解析する時点で問 題となる.

\section{1 .1 エントリー時点}

プロトコールで決められた選択基準に合致し，除外基 準に抵触しない適格患者（eligible patients）が当該 RCT への参加に合意し, 治療を受ける前に, いずれかの治療 群に無作為に割り付けられるのであれば選択バイアスは 生じない，無作為化の重要性は前節ですでに述べたとこ ろである. 選択バイアスは, 担当医師の判断でこの患者 にはあの治療法は望ましくないと判断して無作為割り付 けに関わらず担当医師の望む治療法を選ぶことにより生 じる. RCT に参加する施設の医師に要求される基本的条 件とは「ぞちらの治療法が優れているかわからないから 参加する」である。 この命題に疑問を持つ医師は当該 RCT に参加すべきでない，そらしないと，割り付け違反 が生じたり，試験参加に同意をした適格患者が担当医師 の判断で試験にエントリーできない可能性が高くなる. 後者の状況が多く発生すると, 上記の意味での狭義の選 択バイアスは生じないものの，実際にエントリーした患 者集団は，プロトコールで決めた適格基準を満たす患者 母集団とは少々異なった集団となるといら広義の選択バ イアスが生じることになる.

\subsection{2 解析時点}

統計解析（評価）に組み入れる「症例」を決定すると いら目的でプロトコールから逸脱する患者を中心に症例 検討会が行われる。しかし，この手続き自体が選択バイ アスに直結するのである。一旦，試験にエントリーして 割り付けられた患者は原則として解析対象から除外して はいけないのである，もちろん，患者には脱落する権利 はあるものの, 可能な限り, 中止, 脱落した患者のデー 夕は解析に組み入れなければならない，直感的には，治 療の効果（作用）で中止，脱落しなければならなかった 「効かなかった」患者のデータを除いて解析すれば, 明ら かにその治療が効くほうにバイアスをかけていることに なる。つまり都合の悪いデータを捨てて評価しているこ とにつながることは理解できるだろう。しかし，理由は それだけではない，この「割り付けた患者，つまり，プ ロトコールにしたがって治療しょうとした患者はすべて 割り付けられた群の解析対象にする」原則を「ITT の原 則（intention-to-treat principle)」という. 1998 年に公布さ れた ICH ガイドライン「臨床試験のための統計的原則」
（Statistical Principles for Clinical Trials）ではこの原則にし たがった解析対象を「最大の解析対象集団 (FAS, Full analysis set）」と定義し，「治験実施計画書に適合した集 団 (PPS, Per Protocol Set)」と区別している.

\subsection{PPS と FAS}

ではなぜ ITT の原則が治療効果を評価するには必要な のだろらか? それには，PPS と FAS の違いを明確に理解 する必要がある，この両者の違いを考えるには，実験室 での治療効果と臨床現場での治療効果を比較してみれば 分かりやすいかもしれない. PPS は前者に近似的に対応, FAS は後者に対応する．例えば，実験室での動物実験で は動物が逃げないように「籠」の中で飼育・管理するこ とができる。このように管理された環境では，動物には 人間のように実験者に逆らうことができないので，治療 の副作用でとても耐えられない状況(と動物が思っても) でも「実験者は冷酷にプロトコール通りに実験が可能」 となる。

これを臨床現場にあてはめてみると，PPS といらのは 「プロトコール通りに治療を持続して受けることのでき た集団」を意味し患者全体からすると極めて偏った集団 となってしまう恐れがある。この偏った集団に拈ける治 療効果はいったいなにを意味するのだろらか? そ机が 「治療」の真の効果といえるのだろらか? その結果は慎重 な解釈が必要である。

しかし，多くの，後期 2 相，第 3 相などの臨床試験に 求められているのはこの治療法が使用される臨床現場で の評価である。臨床現場では何が起こるか予測不可能で ある，間違い，違反，(予定日に）来院せず，医者に対す る不信感（人間関係の悪化）でコンプライアンスが悪く なる, 副作用で中止, 脱落, etc. いちいち, 除外してい たら臨床現場での評価になり得ない。むしろ，これらの 現象はすべて「ある治療方針で治療しょらとした結果」 であると考光、「決められた治療方針によって治療しょう とした効果」を無作為割付によってエントリ一時点の選 択バイアスを排除してシミュレーションしているのが FAS と考兄られる.たと光ば, 薬剤 A, B を比較する RCT で

1. 薬剤 A を投与された患者の $20 \%$ が何らかの理由で 脱落

2. 薬剤 B を投与された患者の 40\%が何らかの理由で 脱落

3. 薬剤 A，B を投与されプロトコールにしたがって試 験期間を完了した患者での効果は，それぞれ $p_{A}, p_{B}$ と仮定しょう。この RCT で期待される薬剂 $\mathrm{A}$ 群の FAS の効果は $0.8 p_{A}$ であり, 薬剤 $\mathrm{B}$ 群のそれは $0.6 p_{B}$ となり, 
その差は $0.8 p_{A}-0.6 p_{B}$ である. 一方, PPS での効果差 $p_{A}-p_{B}$ はとなる. どちらが真の薬剤効果の差であろう か?

\section{3 評価バイアス}

RCT のエンドポイントは表 5 にみるように, 客観的な 臨床検查值のようなものから，かなり主観的判断に依存 する自覚症状・他覚所見などまで様々である．投与され ている薬を知ってしまうと，主観的なエンドポイントの 評価に大きな影響を受ける可能性があることは誰も否定 しないだろう。先入観が評価をまげてしまう。新薬に期 待している担当医は新薬の効果を過大評価しやすいし, 批判的な担当医は過小評価しやすいまた，治療を受け る患者にしても同様で，その「知識」が自覚症状の判断 に影響を拉よ淁すことはめずらしくない，この種の評価 バイアスを防ぐ方法が二重盲検試験（double-blind trial） に代表される盲検化 (masking, blinding) であり，その道 具がプラセボ（placebo）である.

\subsection{1 盲検化}

当然ながら，盲検化の重要性はエンドポイントの主観 性, 客観性に大きく依存するものの客観的なエンドポイ ントはそ机核ど多くはない，主観的評価の代表は自覚症 状であり，それをエンドポイントとする試験であれば必 ず盲検化が必要であることは言うまでもない。しかし， 日本では，自覚症状がエンドポイントであるにも関わら ず, 対照を置かない single-arm trial のなんと多いことか! それは明らかに治療効果を過大評価しやすい，一方「死 亡」は客観的と言光るだろらか？「死因にかかわらず死 亡」をエンドポイントとする場合は問題はないだろう。 しかし，「特定の死因」をエンドポイントにすると問題は 容易ではなくなる。 二人の病理学者に見てもらっても答 えが異なるケースが少なくないのだから．

一方, 解析もブラインドで行ら必要がある. 統計解析 は, 解析結果をいくらでも変光る要素がある, つまり, データの変換をするか否か，投与開始からの差あるいは 変化率, ぞちらを計算するか, 差をとるかオッズ比をと るか，共分散分析をするか否かなぞ ..ここれらの細かい 選択の連鎖によって結果が変わるのだから，特に，製薬 会社の解析チームはとの解析の結果によって治験中の新 薬が承認されるか否かが決まるのであるから事前に決め た統計解析計画書にしたがって解析プロセスをシステム 化し，そのブラインド化は必須となっている.

\subsection{2 プラセボ}

プラセボは active ingredient を含んでいないもので，か つ, 概観上は実薬と全く区別がつかない, 匂い, 色, 形, 味... などすべての点で. もちろん, プラセボ手術など はありえないので，主に経口凰（tablet, capsule），注射剂 に限定される，RCT に打けるプラセボの役割は主に，プ ラセボ効果と盲検化である.

「プラセボ効果 (placebo effect)」とは「ある程度の効 果が分かっている治療であれ，全く効く要素のない治療 であれ，「治療を受けていること」に正の反応をする効 果」を指す，たとえば，高血圧患者は治療を受けている といら安心感から血圧が下がる傾向が強い（様々な心配 事が軽減されて血圧が下がる)，また，精神的な要素の多 い自覚症状も治療を受けているといら安心感から自覚症 状も軽減される傾向を示す．この点を RCT のデザインに 反映させることは極めて重要となる，例えば，新薬を投 与する治療群（active treatment group）と全くなんの治療 をしない無治療群（untreated group）を対照とした臨床試 験をよく目にする。しかし，

1. 新薬の投与群の効果 $=$ 新薬の効果 + プラセボ効果

2. 無治療群 $=$ 無治療群に割付けられた精神的ダメージ の効果

であるから，この比較からは新薬の効果は推定できな い!ところが，プラセボ群に盲検下で割付けを行えば

1. 新薬の投与群の効果 $=$ 新薬の効果 + プラセボ効果

2. プラセボ投与群 $=$ プラセボ効果

となるから，この比較からプラセボ効果が差し引きゼロ で新薬の効果が推定できるのである。また，概観上の区 別がつかない特性によりブラインドの役割も果たせるの である。無治療群ではブラインドにもならない。また， 外見の異なる薬剤を比較しなけ机ばならないRCT でも プラセボは有効である。例兑ば, 薬剤 $\mathrm{A}$ は「丸い容器」, 薬剂 B は「細長い容器」とすると，このままではブライ ンドは無理である。しかし，薬剤 A に「プラセボが入っ ている細長い容器」を添える, 一方, 薬剤 B セボの入っている丸い容器」を添えてつねにこの二つの セットで薬剤を投与することにすれば外観上区別がつか ず，ブラインドが成立する。 この方法を二重ダミ一法 (double-dummy technique) と言う.

\section{4 割り付けバイアス}

動物実験のように実験の開始時点で実験に使用する動 物全部を用意できる場合にはそれぞれの個体の特性を考 慮して無作為化に基づく実験計画を行らことが可能で, その結果，比較される群はかなり均質な群となる。しか し, 臨床試験では, 将来来院してくる患者を対象として 行うのであるからたとえ，無作為割り付けを実施しても かなり均質な群に分けることは難しい。これを割り付け バイアス（allocation bias）という．無作為に割り付けを 行えば，総ての特性值が確率的にバランスされ，一方の 
群にある変数の高い個体が多く集まるという可能性は小 さくなる. しかし，無作為化は各群の特性を均一にする 「可能性が大」なのであって「必ず保証するものではな い」. したがって, 時にはいくつかの因子に関してバラン スが保てないことも起こりえる. 特に標本の大きさが少 数の場合には偏りを生ずる確率も高くなる. したがって, 重要な（観測結果に影響を与兄る）背景因子(交絡因子) がある場合にはそれぞれの因子を $2-3$ つのカテゴリー に分けて，それぞれのカテゴリーの中で割り付けを無作 為化する層別無作為化（stratified randomization）を実施 する必要が生じる。または，交絡因子の分布の偏りを強 制的に最小化する最小化法（Minimization）を実施する. このように無作為割り付けは「似た顔をもつ」群に分け る重要な道具であるが，しかし，いずれにしても重大な 交絡因子が存在する場合には解析に組久込む必要性があ る. その理由の一つは，その僅かな不均衡による影響を 解析で調整し，交絡因子によるバイアス (confounding bias）を小さくする，もら一つの理由は，交絡因子によ る変動部分を除去することによって治療効果の検出力を 高めることができる点である. このための手法としては

1. 反応が計量值であれば，共分散分析 (analysis of covariance).

2. 反応が 2 值であれば，ロジスティック回帰分析 (Logistic regression analysis)

3. 反応がイベント発生までの時間であれば Cox の比 例ハザードモデル (Cox proportional hazard model) などが代表的である。

\section{5 公表バイアス}

新薬開発に携わる製薬企業, 補完代替医療に携わる企 業が計画した試験で結果がネガティブであれば公表され る可能性は小さいだろう。研究者にしても思うような結 果がでなければ論文を投稿しょらとしないだろら。たと え，論文を投稿しょうとしても雑誌の編集委員会はネガ ティブな論文は掲載価值が低いと考兄て論文採択を否決 してしまらかもしれない（最近はコクラン共同計画の影 響でネガティブな結果も掲載する機会は増えているが). つまり，「公表される，されない」の基準が研究結果の 「ポジティブかネガティブ」つまり, 統計的有意差の有り 無しに強く関連している。したがって，公表された論文 だけを検索してこれまで実施されてきた類似治療法の効 果をメタ・アナリシスで整理しょらとしても，明らかに ポジティブの方向にバイアスがかかってしまう。これを 公表バイアス (publication bias) と言う。その典型例とし ては, 癌の化学療法の分野の成績が有名である. 進行性 卵巣癌患者に対する多剂併用療法とアルキル化薬単独療
法との比較試験では，文献サーチで選択された研究に基 づいて治療効果を整理した結果では多剤併用療法の方が 有意に生存率が大きかった $(p=0.0004)$ のに対し，癌の 国際癌データバンク（International Cancer Data Bank）に 登録された試験の成績を整理した結果では有意な治療効 果の差は観察されていなかった（ $p=0.17 ）$ のである。こ の上らな公表バイアスを防ぐためには, 全ての RCT を登 録制にしてその結果の公表を義務化する必要があるう. しかし，それは可能だろらか? 人類の永遠の課題かもし れない，したがって，市場に出回っている薬品の効果は その添付文書にかかれている効能効果を割り引いて考兄 る必要があることを示唆している。しかし，どの程度割 り引くかはわからない。

\section{RCT のプロトコールの概要}

ここでは, RCT のプロトコールの概要を, 現在実施中 である月経困難症に対するフランス海岸松エキス（ピク ノジェノール）（Kohama and Suzuki, 1999）の二重盲検試 験（試験責任医師，鈴木信孝日本補完代替医療学会理事 長）を例にして解説しょう。ピクノジェノールは有効成 分としてプロアントシアニジンのほか，数十種類のフラ ポノイドを含有し，強力なフリーラジカル消去作用を有 している. アメリカ，日本では栄養補助食品に分類され ているがスイス，ポルトガルでは医薬品としての認可が 得られている.

1. 試験の目的を明確に宣言する

栄養補助食品フランス海岸松エキス（ピクノジェノー

ル）の月経困難症に対する臨床的有効性を検証する.

2. 試験の種類

プラセボ対照多施設二重盲検並行群間比較試験

3. RCT の結果を適用できる患者集団の適格条件 （選択・除外基準）を明確に定義する。

選択基準

次の条件を満たす患者：

(a) 20 歳以上で月経困難症と診断された患者

（b）明らかな月経痛が過去連続して 3 回経験している 者

除外基準（の一部）

（a）明らかに手術適応と考兄られる疾患，例兄ば粘膜 下筋腫等を有する患者.

(b) Gn-RH analogue, danazol または，ホルモン剂など の治療を受けている患者.

（c）薬物や松，オリーブオイル等の植物性オイル，カ プセル成分ゼラチンなどにアレルギーのある者

(d) 過去 6 ケ月以内にピクノジェノールの使用経験の 
ある者。

(e) 本試験開始前 4r月以内に他の臨床試験に参加し たもの，もしくは過去 1 年間に被験者として 2 回 以上臨床試験に参加した者.

(f) 「妊娠中, 授乳中および期間中に妊娠を計画してい る者.

（g）胃潰瘍，十二指腸潰瘍，胃弱の者.

(h) 抗凝固療法中の者.

（i）出血性素因，出血性疾患の既往のある者。

（j）その他，医師が不適当と判断した者.

\section{4. 主要評価項目 (primary endpoint)}

本試験の主要評価項目は自覚症状（痛み）をスコア化 し，20\%以上痛みスコアが軽減したものを有効とした有 効率とする（生体反応の偶発的な变動範囲は，慣例的に 20\%以内といわれている).

5. RCT 飞必要な症例数を見積もり, 試験期間に必要な 症例を獲得できるように適正な数の施設に協力を依 頼する. 症例数設定の根拠は検証的試験では必須で ある。

目標症例数は食品試食群 75 名, プラセボ試食群 75 名 とする。 その根拠は以下の通りである。予備臨床実験よ り判断して, 食品試食群の有効率は $67 \%$, プラセボ群 は $40 \%$ と設定し, 有意水準を $\alpha=0.05$ とし, 検出力を 90 $\%$ とすると 1 群 61 例, 2 群で 122 名となる. 予備実験 より脱落率を $18 \%$ 程度とすると，必要症例数は 122 / $(1-0.18)=148$ 例となる.

6. 患者の同意を得る

RCT の実施に先立ち，患者本人に少なくとも次の事項 について分かりやすく説明し，質問についても丁寧に答 えなければならない。

(a) 本試験の目的と方法

（b）本試験で使用される治療法の予期される効果及び 副作用

（c）他の治療法の有無及びその内容

（d）試験に参加する場合の人権保護に関する必要な事 項

（e）試験への参加に同意しない場合であっても不利益 は受けないこと

（f）試験への参加に同意した場合であっても随時これ を撤回できること

（g）緊急時の問い合わせ先の電話

これらの説明文書（非専門用語を中心にした分かりやす い文書）及び同意書を手渡し，本試験への参加について 患者本人の自由意志による同意を文書で得る. 必要なら, 患者が自宅に戻って家族と相談する時間を与兄る．説明 文書の最後に同意書のページを掲載し，医師，患者，法
定代理人（患者が未成年の場合）の署名欄を作る

このように，現実にエントリ一する患者は適格条件で 定義された患者集団ではなく，その中から試験に同意し なかった，あるいは，最初から脱落してしまった患者等 が除かれた集団であるが，このことにより治療法の比較 にバイアスが生じることはない，しかし，同意しない患 者数が多いと，適格条件で定義された患者集団とはかけ 離れた集団となっている恐れがあり，極端な場合には， 得られた結果を適格条件で定められた対象に一般化する ことさえ難しくなることに注意する必要がある.

7. 試験栄養補助食品

(a) 試験食品：ピクノジェノール. 1 カプセル中, ピ クノジェノール $15 \mathrm{mg}$, オリーブオイル $235 \mathrm{mg}$ 含 有.

（b）プラセボ食品：1 カプセル中，オリーブオイル 250 $\mathrm{mg}$ 含有.

上記の食品の形態は二重盲検を達成させるため識別不能 試験を実施していなければならない。

8. 用法用量と投与期間の明示

投与量は，試験食品，プラセボともに $4 \mathrm{cap} /$ 日（朝， 夕, 各 2 cap 内服). 試験食品はピクノジェノールとして $60 \mathrm{mg} /$ 日投与. 投与方法は，経口投与であり，月経第 2 周期の 8 日目から月経第 4 周期の 7 日目まで服用する. 試験食品, プラセボともに 1 回 2 カプセルを 1 日 2 回 朝，夕食直後に経口投与する（食事中に服用しても可）. なお，飲久忘れた場合は，飲久忘孔た分量を翌日追加し て服用することはしない．

9. 併用薬剤，併用禁止薬剂の明示

除外基準で記載されている薬剂は当然併用禁止とな る.

（a）摂取期間中の鎮痛剤の併用は，本人が常用してい るものに限り使用できる，ただし，向精神薬，ビ タミン郕拉よび漢方薬，他の栄養補助食品は原則 併用しないのが望ましいが，常用している場合は この限りではない。

（b）消化器系薬剤は, 症状により併用は可能である.

(c) その他，ピクノジェノールの効果に直接影響を及 ぼさないと考觉られる薬剤の併用は必要に応じて 許可する.

（d）新規の理学療法（銊炎など）は行わない.

（e）患者がこれまで継続していた治療のらち，中止す れば明らかに症状を悪化させると医師が判断した 当該治療法については，その治療を継続してもよ い.

（f）摂取中，発疹，胃痛，激しい下痢，著しい不眠， 手の震光，目まい，ふらつき，しびれ等副作用と 
考えられる症状を認めた場合は直ちに中止し，担 当医淿申告.

10. 無作為割り付けの方法と試験への登録

登録と割り付けは第 3 者の登録センターで電話あるい はFAXにより実施されることが多い。その際, 登録 チェックリストを作成し，担当医師は登録に必要なすべ ての情報（選択・除外基準に適合しているか否か）を記 載してから登録センターに連絡するのが望ましい.

11. 主要な観察・検査項目

（a）被験者背景：姓名，年齢，常用している薬剤や栄 養補助食品の使用状況，除外基準項目のチェック

(b) 日記の記載：月経開始前日から月経 7 日目まで下 腹部痛, 腰痛に関してビジュアルアナログスケー ル（VAS）飞記載する. 月経痛の際使用した常用 薬剤の種類, 量を記載する. 飲久忘孔の有無, 副 作用について記載する.

(c) QOL 表の記載: 月経開始前日と月経初日の健康プ ロファイル型尺度（SF-36 QOL スコア）拈よび追 加カテゴリーとして頭痛, 睡眠, 排便, 浮腫, 肌 荒れ，嘔気の 6 項目を記載する.

12. 主要評価項目の統計解析方法

主要評価項目である有効率の食品群とプラセボ群とで の比較を $x^{2}$ 検定により行う.

一般に, 主要評価項目を構成する変数のベースライン 值と施設は共変量 (covariate) として統計解析で調整す るのが望ましい，また，主要評価項目が連続量である場 合, 途中脱落した症例については評価時点のデータが欠 損值となり FAS などの ITT 型で解析する際にその取り 扱いが問題となる。評価時点前の最後に観測されたデー 夕を評価時点のデータと置き換えて解析する方法 (LOCF, the last observation carried forward) がよくとられ るが, 評価項目の経時的プロファイルの推定にはなじま ない. 一方, 主要評価項目が有効性の有無のような 2 值 の場合には, 途中脱落の場合には分母だけに含めことが できる，といら意味で取り扱いが容易と考兄られている が, 有効率の意味が異なってくる. これらの欠損值に係 わる問題は統計学的には未解決の問題といっていいだろ ら.

13. 試験実施計画書に違反した症例の取り扱い

14. 中止基準を明示する.

15. 有害事象, 副作用の解析

一般に, 有害事象の解析にあたっては, 事象別あるい は総計で患者当たりの割合（\%) で評価することが慣例 のよらである. しかし, 脱落, 中止, プロトコールの不 遵守などの要因で, すべての患者が同じ期間試験薬を服 用する結果にはならない,つまり, 有害事象の発生頻度
が服用期間に比例すると仮定して, 患者によって服用期 間の長さの違いを考慮にいれた人時間（person-time）で の評価

$\frac{\text { 有害事象の延べ発現回数 }}{\text { 延べ観察期間 }}$

も取り入れる必要が生じる.

\section{RCT の論文の書き方}

RCT が最も質の高い科学的根拠を提供できると期待 される研究デザインであるためには,「適切にデザインさ れ, 適切に実施され, 適切に解析され, さらに適切に報 告される」ことが重要である. しかし，現実には不適切 なデザイン, 実施, 解析も少なくなく, かつ, 不適切な 報告も少なくないため，こ机らの不適切さの連鎖による バイアスのかかった結果とその解釈は治療法に対する 誤った評価を与えてしまう危険性が大きい，このような 観点から，少なくとも， RCT の結果を報告する際には少 なくともこれだけの情報は記述するべきであるというミ ニマム・リクワイアメントが提案されている. これが CONSORT (CONsolidated Standards Of Reporting Trials; Moher et al, 2001) である. その解説は Altman et al (2001) に詳しい。その詳細は原文を扔読みいただくとして，こ こでは, その中から RCT の論文を書くときにチェックす べきチェックリストを表 6 亿掲載しよう。少なくとも, ここに揭載されている項目については詳細かつ正確に記 述する必要がある.

な拉, RCT についての詳細は拙著（無作為化比較試験, 近刊）を参考にされたい.

\section{参 考 文 献}

1) 丹後俊郎. 統計学のセンスーデザインする視点・データを 見る目. 医学統計学シリーズ 1. 朝倉書店. 1998.

2) 丹後俊郎. メタ・アナリシス入門ーエビデンスの統合をめ ざす統計手法. 医学統計学シリーズ 4. 朝倉書店. 2002.

3) 丹後俊郎. 無作為化比較試験ーデザインと統計解析. 医学 統計学シリーズ 5. 朝倉書店. 2003.

4) Altman DG, Moher D, Schulz KF. The reviesed CONSORT statement for reporting randomized trials: explanation and elaboration. Ann Intern Med 2001; 134: 663-694.

5) Moher D, Schulz KF, Altman DG. The CONSORT statement: revised recommendations for improving the quality of reports of parallel group randomized trials. Ann Intern Med 2001; 134: 657-662.

6) Kohama T. and Suzuki N. The treatment of gynaecological disorders with pycnogenol. Eur Bull Drug Res 1999; 7 (2): 30-32. 
表 6 CONSORT（2001）によるRCT の論文を書く（報告する）場合に含めるべき項目のチェックリスト．原本では評価項目はアウト カム (outcomes) となっているが，ここでは評価項目とする

\begin{tabular}{|c|c|c|}
\hline 節・トピック & 項目番号 & 記述内容 \\
\hline タイトル・抄録 & 1 & 参加者（participants）がぞのように介入群に割付けられたかの方法 \\
\hline 緒言 & 2 & 科学的背景と論理的根拠 \\
\hline \multicolumn{3}{|l|}{ 方法 } \\
\hline 参加者 & 3 & 適格基準，試験が実施された診療施設，診療環境 \\
\hline 介入 & 4 & 介入の正確な詳細 : なにが, いつ, どこで, どのように実施されたか \\
\hline 目的 & 5 & 具体的な目的と検証したい仮説 \\
\hline エンドポイント & 6 & $\begin{array}{l}\text { 主要評価項目，副次的評価項目（primary endpoints; outcomes）の明確な定義，その質を } \\
\text { 向上させた工夫 }\end{array}$ \\
\hline 症例数 & 7 & 目標症例数の設定根拠，中間解析の方法と中止基準 \\
\hline \multicolumn{3}{|l|}{ 無作為化 } \\
\hline 割付け番号 & 8 & 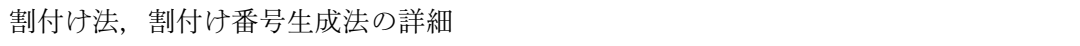 \\
\hline 割付けの隠蔽 & 9 & 無作為割付の方法 (中央電話, FAX), 試験終了まで割り付け番号が隠蔽されていたか \\
\hline 実施法 & 10 & $\begin{array}{l}\text { 誰が割付け番号を作成し，誰が参加者を組み入れ，誰が参加者をそれぞれの群に割付 } \\
\text { けたか }\end{array}$ \\
\hline 盲検性 & 11 & $\begin{array}{l}\text { 参加者, 介入実施者, 主要評価項目の評価者に対する割付けの盲検性の有無, 盲検化 } \\
\text { されていた場合には試験終了まで成功していたか }\end{array}$ \\
\hline 統計学的方法 & 12 & $\begin{array}{l}\text { 主要評価項目の比較に用いられた統計学的方法, 交絡因子の調整, サブグループ解析 } \\
\text { の方法など }\end{array}$ \\
\hline \multicolumn{3}{|r|}{ 业 } \\
\hline 参加者の流水 & 13 & $\begin{array}{l}\text { ダイアグラムを描くことが強調されている. 各群ごとに, 無作為割付けされた人数, } \\
\text { 実際に治療を受けた人数, プロトコールを完了した人数, 主要評価項目の解析対象と } \\
\text { なった人数, 計画された研究のプロトコールからの逸脱した人数とその理由 }\end{array}$ \\
\hline 募集 & 14 & 参加者の募集期間と追跡期間が判断できる日付 ～～～～～～～ \\
\hline ベースライン & 15 & 各群のベースラインの人口統計的分布, 臨床的特性 \\
\hline 解析対象の人数 & 16 & 解析ごとに各群の参加者数, ITT 解析の有無, 結果は実数がわかるように書く \\
\hline 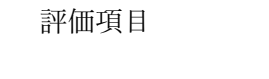 & 17 & $\begin{array}{l}\text { 主要，副次的評価項目それぞれについて各群の結果の要約，effect size の推定と精度 } \\
\text { (信頼区間) }\end{array}$ \\
\hline 補助的解析 & 18 & $\begin{array}{l}\text { 交絡因子の調整，サブグループ解析など他の解析について報告する．その際，推測の } \\
\text { 多重性についても言及する. また，実施された解析がプロトコールに記載されていた } \\
\text { ものか否か }\end{array}$ \\
\hline 有害事象 & 19 & すべての有害事象，副作用を各群ごとにまとめる \\
\hline \multicolumn{3}{|l|}{ 考察 } \\
\hline 解釈 & 20 & $\begin{array}{l}\text { 研究仮説, バイアス・推測精度の低下の可能性とその原因, 評価項目の多重性への考 } \\
\text { 慮 }\end{array}$ \\
\hline 一般化可能性 & 21 & 試験結果の一般化可能性（外的妥当性） \\
\hline 総括的エビデンス & 22 & これまでのエビデンスを合わせた試験結果の総括的な解釈 \\
\hline
\end{tabular}




\author{
ABSTRACT \\ Randomized Controlled Trials for Creating Scientific Evidence of the Efficacy \\ and Safety of Complementary and Alternative Medicine \\ Toshiro TANGO \\ Department of Technology Assessment and Biostatistics, National Institute of Public Health
}

It is well known all over the world that the randomized controlled trial (RCT), is the only study design for experiments involving human subjects that can create evidence of the highest quality regarding the efficacy and safety of a new treatment. In Japan, however, most clinical researchers have shown no interest in RCT and thus the number of good RCTs is quite small. Although the recent development of evidence-based medicine has played a role in promoting RCT among clinical researchers, the number of researchers who can understand what an RCT is, design one properly and analyze data appropriately is also quite small. This situation is also completely applicable to the world of complementary and alternative medicine. In this paper, we shall introduce the reader to the concepts behind RCT and a statistical way of thinking that is indispensable for properly conducting RCT to glean scientific evidence of the efficacy and safety of complementary and alternative medicine.

Key words: effect size, random allocation, bias, confounding factors 